Article

\title{
Characterization of High-Ornithine-Producing Weissella koreensis DB1 Isolated from Kimchi and Its Application in Rice Bran Fermentation as a Starter Culture
}

\author{
Mun So Yeong ${ }^{\circledR}$, Moon Song Hee and Chang Hae Choon *๑ \\ Kimchi Research Center, Department of Food and Nutrition, Chosun University, 309 Pilmun-daero, Dong-gu, \\ Gwangju 61452, Korea; ohno1757@gmail.com (M.S.Y.); cocoajjoa@hanmail.net (M.S.H.) \\ * Correspondence: hcchang@chosun.ac.kr
}

Received: 11 September 2020; Accepted: 23 October 2020; Published: 26 October 2020

check for updates

\begin{abstract}
High-ornithine-producing Weissella koreensis DB1 were isolated from kimchi. Ornithine is produced from arginine via the intracellular arginine deiminase pathway in microorganisms; thus, high cell growth is important for producing ornithine in large quantities. In this study, excellent W. koreensis $\mathrm{DB} 1$ growth $\left(\mathrm{A}_{600}\right.$ : 5.15-5.39) was achieved in de Man, Rogosa, and Sharpe (MRS) medium supplemented with $1.0-3.0 \%$ arginine ( $\mathrm{pH} 5.0)$ over $24-48 \mathrm{~h}$ at $30{ }^{\circ} \mathrm{C}$, and the highest ornithine $(15,059.65 \mathrm{mg} / \mathrm{L})$ yield was obtained by culture in MRS containing 3.0\% arginine for $48 \mathrm{~h}$. W. koreensis DB1 was further investigated as a functional starter culture for rice bran fermentation. After $48 \mathrm{~h}$ of fermentation at $30^{\circ} \mathrm{C}$, the fermented rice bran was freeze-dried and ground. The prepared fermented rice bran contained $43,074.13 \mathrm{mg} / \mathrm{kg}$ of ornithine and $27,336.37 \mathrm{mg} / \mathrm{kg}$ of citrulline, which are used as healthcare supplements due to their beneficial effects. Furthermore, the organoleptic quality of the fermented rice bran was significantly improved, and the fermented product contained viable cells $(8.65 \log \mathrm{CFU} / \mathrm{mL})$ and abundant dietary fiber. In addition, an investigation of its safety status showed that it has no harmful characteristics. These results indicate that the fermented rice bran product produced is a promising functional food candidate.
\end{abstract}

Keywords: Weissella koreensis; rice bran; fermentation; ornithine; functional food

\section{Introduction}

L-Ornithine is used as a healthcare supplement, as it is required for proper immune system and liver function. This non-proteinogenic amino acid has been used to treat liver disorders and is a component of the urea cycle, which removes ammonia from the blood [1]. The administration of ornithine has been reported to reduce stress, improve sleep quality, reduce physical fatigue, increase mental ability [2-4], improve skin aesthetics, promote the synthesis and production of collagen $[5,6]$, and effectively increase muscle growth and prevent obesity by enhancing basal metabolism [6]. Ornithine is widely distributed in various foods, especially in mushrooms and Corbicula japonica, which contain 10-170 mg and $160 \mathrm{mg}$ per $100 \mathrm{~g}$, respectively [1,7]. However, these amounts are substantially lower than those required to satisfy daily requirements (400-1000 $\mathrm{mg}$ ), and the same applies to fish and meat consumption [8].

Lactic acid bacteria (LAB) are industrially important microorganisms, as they are used in starter cultures for fermented food processing because they improve the sensory qualities and food preservation. Moreover, LAB are now the subjects of intensive research because of their health benefits [9]. Kimchi is a LAB-rich food and, thus, a good source of potentially beneficial LAB. Actually, during our previous studies, we isolated LAB from kimchi and investigated their abilities to produce bacteriocin, antifungal 
compounds, exopolysaccharide, mannitol, and $\gamma$-aminobutyric acid and their cholesterol-lowering effects and acid and bile tolerances in the contexts of the food and feed industries [9-14].

Arginine is the precursor of ornithine and is converted by the arginine deiminase (ADI) pathway to L-arginine, $\mathrm{L}$-citrulline, and $\mathrm{NH}_{3}$; thereafter, the $\mathrm{L}$-citrulline produced is converted by ornithine transcarbamoylase to L-ornithine and carbamoyl phosphate. The latter is converted to $\mathrm{NH}_{3}, \mathrm{CO}_{2}$, and ATP by carbamate kinase [15]. The ADI pathway is widely utilized in bacteria, including LAB. Arginine is readily detected in kimchi, grape juice, and wine and is readily degraded by some LAB [16-18]. However, interestingly, in kimchi, the arginine contents fall to almost undetectable levels during fermentation, whereas the total amino acid contents increase slightly due to the degradation of proteinaceous components $[17,19]$, which suggests that the microorganisms possessing the ADI pathway are involved in the process. Ornithine production by the LAB strains Lactobacillus brevis, Weissella confusa, and Weissella koreeensis isolated from kimchi has been previously investigated, but the amounts of ornithine produced were below $1.5 \mathrm{~g} / \mathrm{L}[6,17]$.

In this study, we isolated and identified an effective ornithine-producing LAB from kimchi. The isolates were then assessed for safety, which included investigations of their hemolytic activity, undesirable biochemical characteristics, and antibiotic resistance, and this was followed by an investigation on the effects of culture conditions on the growth of the isolates and their ability to produce ornithine. To explore practical applications, we selected one isolate as a functional starter culture for rice bran fermentation and characterized the fermented rice bran obtained along with a sensory evaluation.

\section{Materials and Methods}

\subsection{Kimchi Sampling and Isolation of $L A B$}

A total of 38 kimchi samples were collected from 29 different regions in Korea, macerated using a hand blender (Hanil, Seoul, Korea), and filtered through a thin sterile cloth. The filtrates were serially diluted and spread on de Man, Rogosa, and Sharpe (MRS; Difco, Sparks, MD, USA) agar containing $2.0 \% \mathrm{CaCO}_{3}$. The plates were incubated at $30{ }^{\circ} \mathrm{C}$ for $48 \mathrm{~h}$; thereafter, colonies that formed a clear zone were selected as tentative $\mathrm{LAB}$ strains.

\subsection{Identification of Isolates}

Isolates were identified based on their morphological properties under a microscope, by a catalase test, by Gram-staining, and according to $16 \mathrm{~S}$ rDNA sequence analysis [20], which was compared with sequences available in GenBank (https://www.ncbi.nlm.nih.gov/) using CLUSTAL W (https://www.genome.jp/tools-bin/clustalw).

Random amplified polymorphic DNA (RAPD)-PCR was performed using the M13 primer, which is specific for Weissella species [21]. The PCRs were performed in a PCR unit (CP2-03 Thermal Cycler, Corbett Research, Mortlake, Australia) using annealing temperatures of 30, 35, 40, 45, 50, or $55^{\circ} \mathrm{C}$. The PCR products were separated by electrophoresis on $1.5 \%(w / v)$ agarose-TAE ( $40 \mathrm{mM}$ tris-acetate, 1 M EDTA, pH 8.2) gels using the BioFACT ${ }^{\text {TM }} 1 \mathrm{~Kb}$ Plus DNA Ladder (Biofact, Daejeon, Korea) as a size marker [13].

\subsection{Thin Layer Chromatography (TLC) and High-Performance Liquid Chromatography (HPLC)}

To prepare filter-sterilized culture supernatants, isolates were cultivated in MRS $+1.0 \%$ arginine broth for $48 \mathrm{~h}$ at $30{ }^{\circ} \mathrm{C}$, centrifuged $\left(9950 \times g, 15 \mathrm{~min}, 4{ }^{\circ} \mathrm{C}\right)$, and then filtered $(0.4 \mu \mathrm{m}$ pore size, Advantec, Dublin, CA, USA). Ornithine production by isolates was determined qualitatively by spotting filter-sterilized culture supernatants onto TLC silica gel $60 \mathrm{~F}_{254}$ plates (Merck, Darmstadt, Germany). The mobile phase used was a 1-butanol/acetic acid/distilled water (12:3:5) mixture, and the plates were subsequently stained with a $0.5 \%(w / v)$ ninhydrin solution $[22,23]$. 
HPLC was used to determine the amino acid contents in the culture supernatants of the isolates and fermented rice bran. For HPLC analysis, the culture supernatants were derivatized using O-phthalaldehyde-fluorenylmethyl chloroformate (OPA-FMOC) [24] and analyzed using an HPLC unit (Ultimate 3000) equipped with a Fluorescence detector, an UV detector (Agilent 1260, Agilent, Santa Clara, CA, USA), and an Inno C18 column ( $5 \mu \mathrm{m}, 4.6 \times 150 \mathrm{~mm}$; Youngjin, Seongnam, Korea). Elution was performed using mixtures of Solution A ( $40 \mathrm{mM}$ sodium phosphate, $\mathrm{pH} 7.0)$ and Solution $\mathrm{B}$ (methanol/acetonitrile/water $=45: 45: 10$ ) using the following program: $\mathrm{A} / \mathrm{B}$ at $95: 5$ for $0-24 \mathrm{~min}$, 45:55 for 24-25 $\mathrm{min}, 10: 90$ for 25-34.5 $\mathrm{min}$, and $95: 5$ after $34.5 \mathrm{~min}$ at a flow rate of $1.5 \mathrm{~mL} / \mathrm{min}$ [25].

\subsection{Effects of Culture Conditions on Growth}

\subsubsection{Temperature}

Overnight-cultured LAB isolates were used to inoculate $(1.0 \%, v / v)$ MRS broth and then incubated at $5,10,15,25$, or $30^{\circ} \mathrm{C}$ for $24-288 \mathrm{~h}$. Growth was measured every 4 or $8 \mathrm{~h}$ by measuring absorbance at $600 \mathrm{~nm}\left(\mathrm{~A}_{600} ;\right.$ Ultrospec 2100 Pro, Biochrom, Cambridge, UK). In addition, viable counts at maximum $\mathrm{A}_{600}$ were determined using the plate method [26].

\subsection{2. $\mathrm{pH}$}

Overnight-cultured LAB isolates were used to inoculate (1.0\%) MRS and MRS $+1.0 \%$ arginine broth; the $\mathrm{pH}$ values were adjusted to $\mathrm{pH} 5.0,6.0,7.0$, or 8.0, and the mixtures were incubated at $30{ }^{\circ} \mathrm{C}$ for $24 \mathrm{~h}$. Thereafter, cell growth was determined by measuring absorbance at $600 \mathrm{~nm}$ (Biochrom, Cambridge, UK).

\subsubsection{Arginine (Precursor) Concentrations}

The dependence of LAB growth on the arginine (as a precursor of ornithine) concentration in the MRS broth was examined. Arginine was added to MRS broth at $0.5,1.0,2.0$, or $3.0 \%(w / v)$, and the $\mathrm{pH}$ values were adjusted to optimum values based on the results described in Section 2.4.2 above. Cultures supplemented with arginine at $0.5-3.0 \%$ without $\mathrm{pH}$ adjustment were used as controls. Incubation was performed for $24-48 \mathrm{~h}$ at $30^{\circ} \mathrm{C}$, and cell growth was determined at $600 \mathrm{~nm}$ (Biochrom, Cambridge, UK)). The conversion of arginine to ornithine was assessed by TLC.

\subsection{Safety Assessment}

\subsubsection{Harmful Enzyme Activities}

Enzymatic activities were assayed using an API-ZYM kit (BioMérieux, Lyon, France) according to the manufacturer's instructions. Harvested LAB cultures were resuspended in sterile distilled water (McFarland standard 5), spotted (65 $\mu \mathrm{L})$ into each cupule, and incubated at $37^{\circ} \mathrm{C}$ for $4 \mathrm{~h}$. ZYM-A and ZYM-B kit reagents were then added to each cupule, and enzyme activities were determined after allowing the reactions to continue for $5 \mathrm{~min}$.

\subsubsection{Antibiotic Susceptibility and Hemolysis}

$\mathrm{LAB}$ were evaluated for their susceptibilities to antibiotics according to the technical guidelines issued by the European Food Safety Authority (EFSA) [27]. LAB strains cultivated overnight in MRS broth were harvested $\left(9950 \times g, 15 \mathrm{~min}, 4^{\circ} \mathrm{C}\right)$ and resuspended in Mueller-Hilton (MH; Difco, Sparks, MD, USA) broth containing $0.5 \%$ dextrose at a concentration of $~ 7.0 \log$ CFU $/ \mathrm{mL}$. The minimal inhibitory concentrations (MICs) of ampicillin, chloramphenicol, erythromycin, gentamycin, kanamycin, streptomycin, tetracycline, and vancomycin (Sigma, St. Louis, MO, USA) were then determined. Briefly, each antibiotic was added to aliquots of the MH suspension and incubated for 24-48 $\mathrm{h}$ at $30{ }^{\circ} \mathrm{C}$ without shaking. Cell growth was assessed by measuring absorbance at $600 \mathrm{~nm}$ (Biochrom, 
Cambridge, UK). Cultures in $\mathrm{MH}$ broth containing $0.5 \%$ dextrose for $24-48 \mathrm{~h}$ at $30{ }^{\circ} \mathrm{C}$ in the absence of any antibiotic were used as controls [10].

For the hemolysis test, LAB cells were streaked on blood agar containing 7.0\% horse blood (Oxoid, Hampshire, UK). Plates were incubated for $24-48 \mathrm{~h}$ at $30{ }^{\circ} \mathrm{C}$ to detect $\alpha$-hemolysis or for $24-48 \mathrm{~h}$ at $30^{\circ} \mathrm{C}$ and for $24 \mathrm{~h}$ at $4{ }^{\circ} \mathrm{C}$ to detect $\beta$-hemolysis $[10,28]$ and then assessed for the presence of clear zones around colonies. Bacillus cereus ATCC 14579 was used as a control for the hemolysis assay [10].

\subsubsection{Production of Biogenic Amines}

LAB were cultured in MRS $+1.0 \%$ arginine for $48 \mathrm{~h}$ at $30^{\circ} \mathrm{C}$, harvested $\left(9950 \times g, 15 \mathrm{~min}, 4{ }^{\circ} \mathrm{C}\right)$, filtered $(0.4 \mu \mathrm{m}$, Advantec), freeze-dried, and concentrated 5-fold in distilled water. $2 \mathrm{~mL}$ of samples were then added to $10 \mathrm{~mL}$ of $0.4 \mathrm{M}$ perchloric acid-5.0\% trichloroacetic acid, and then $0.2 \mathrm{mg}$ of 1,7-diaminoheptane (internal standard) was added. The mixtures were then homogenized, benzoylated, dissolved in $0.5 \mathrm{~mL}$ of $50 \%$ methanol, and subjected $(20 \mu \mathrm{L})$ to HPLC analysis [29]. The HPLC unit was equipped with a SunFire C18 column $(3.5 \mu \mathrm{m}, 4.6 \times 150 \mathrm{~mm}$; Waters, Boston, MA, USA), a Waters 2996 photodiode array detector at $254 \mathrm{~nm}$, and the Waters Empower software (Waters 2695, Waters, Boston, MA, USA). Gradient elution was performed using aqueous methanol mixes, as follows: $50 \%$ methanol for the first $15 \mathrm{~min}$ followed by a linear increase to $90 \%$ methanol for $10 \mathrm{~min}$ and then a decrease to $50 \%$ methanol for $5 \mathrm{~min}$, and then maintenance at $50 \%$ methanol for the next $5 \mathrm{~min}$ at a flow rate of $0.4 \mathrm{~mL} / \mathrm{min}[30]$.

\subsection{Preparation of Starter Culture and Rice Bran Fermentation}

Based on the above test results, a single LAB strain was selected as the rice bran fermentation starter and cultured in MRS broth for $24 \mathrm{~h}$ at $30^{\circ} \mathrm{C}$, harvested $\left(9950 \times \mathrm{g}, 15 \mathrm{~min}, 4^{\circ} \mathrm{C}\right)$, washed twice with sterile distilled water, and suspended in sterile distilled water containing the same volume of culture.

Rice bran powder was obtained from Henanum Co., Ltd. (Yangpyeong, Korea). The rice bran slurry consisted of $20 \%(w / v)$ rice bran powder supplemented with $2.0 \%(w / v)$ glucose, $3.0 \%$ corn steep liquor, and $1.0-3.0 \%$ arginine in distilled water and was autoclaved $\left(121^{\circ} \mathrm{C}, 15 \mathrm{~min}\right)$ and immediately cooled. The prepared starter culture was inoculated (1.0\%; equivalent to $\sim 6 \log \mathrm{CFU} / \mathrm{mL}$ ), fermented for $48 \mathrm{~h}$ at $30^{\circ} \mathrm{C}$, and filtered through four layers of sterile thin cloth; this fermented rice bran filtrate was used to investigate the effect of $\mathrm{pH}$ and to monitor cell survival. The fermented rice bran was freeze-dried (SFDSM12, Samwon, Seoul, Korea), ground using a hand blender (BW-3000, Buwon, Daegu, Korea), and subjected to amino acid determination and sensory evaluation. In the sensory evaluation test, raw rice bran and freeze-dried non-fermented rice bran were also used as controls.

\subsection{Characterization of Fermented Rice Bran}

\subsection{1. $\mathrm{pH}$ and LAB Counts}

The $\mathrm{pH}$ of the fermented rice bran was measured using a $\mathrm{pH}$ meter (Fisher Science Education, Hanover Park, IL, USA). The viable cell contents in fermented rice bran were determined by plating onto MRS agar and MRS + 2.0\% $\mathrm{CaCO}_{3}$ agar [26].

\subsubsection{Amino Acid Contents}

Distilled water was added to the prepared freeze-dried fermented rice bran, mixed well, ultrasonicated (PowerSonic 420, Hwasin Tech, Seoul, Korea), and stirred at room temperature for $1 \mathrm{~h}$, and then the mixture was filtered using a $0.2 \mu \mathrm{m}$ regenerated cellulose membrane filter (Sartorius, Göttingen, Germany). The arginine, citrulline, and ornithine contents in the filtrate were determined by HPLC (Section 2.3). 


\subsubsection{Sensory Evaluation}

The sensory evaluations were approved by the Institutional Review Board, Chosun University, Korea (IRB\#2-1041055-AB-N-01). Nine trained students with previous experience of sensory evaluations of food, who had conducted more than 20 analyses per year at the Department of Food and Nutrition at Chosun University (Gwangju, Korea), participated in the evaluation of the fermented rice bran. Each sample (5 g) was served on a white plate, and the sample orders were randomized. The panelists rinsed their mouths with water before scoring the samples and waited for 1-2 min before evaluating subsequent samples. Sensory evaluation was performed by scoring the bitterness, saltiness, savory flavor, hay smell, mouthfeel texture, and overall acceptability using a 5-point scale, where $1=$ very bad, $3=$ moderate, and $5=$ very good.

\subsection{Statistical Analysis}

Data are presented as the means and standard deviations (means \pm SDs) of two or three independent experiments performed in duplicate. Statistical analysis was performed using Duncan's multiple range test (DMRT) for one-way ANOVA and the independent-samples $t$ test. The analysis was performed using SPSS version 26.0 for Windows (SPSS, Chicago, IL, USA), and statistical significance was accepted for $p$-values $<0.05$.

\section{Results and Discussion}

\subsection{Isolation and Identification of Ornithine-Producing $L A B$}

Forty LAB strains were isolated from 38 kimchi samples collected from 29 regions of South Korea. Of these 40 isolates, 11 found to produce ornithine by TLC analysis (data not shown) were selected for further experimentation. All 11 isolates were Gram-positive and catalase-negative; one isolate was coccus-shaped, and other 10 were short-rod-shaped cells. When the 16S rRNA gene sequences (1373-1518 bp) of the 11 isolates were compared with those of LAB strains in GeneBank, one isolate (coccus-shaped) showed $99.38 \%$ homology with Leuconostoc citreum ATCC $49370^{\mathrm{T}}$, whereas the others (short-rod shaped) showed 100\% homology with W. koreensis JCM $11263^{\mathrm{T}}$ (Supplementary Table S1). RAPD-PCR using strain- and species-specific primers has been shown to enable the identification of strains belonging to subspecies of the same species [13]. Thus, the genotypic differences among these 10 closely related strains were analyzed by RAPD-PCR. Of the 10 strains, five strains displaying slightly different RAPD patterns under different annealing temperatures $\left(30-55^{\circ} \mathrm{C}\right)$ were selected (Supplementary Figure S1) and investigated for ornithine production by HPLC. Two isolates, designated Weissella koreensis DB1 and HJ, produced significantly more ornithine than the others, consumed more arginine (Table 1), and were selected for further experimentation.

Table 1. Ornithine production from arginine by lactic acid bacteria (LAB) isolates.

\begin{tabular}{|c|c|c|c|c|c|}
\hline \multirow{2}{*}{$\begin{array}{l}\text { Amino Acid } \\
(\mathrm{mg} / \mathrm{L})\end{array}$} & \multicolumn{5}{|c|}{ Weissella koreensis } \\
\hline & GL & DB1 & $\mathrm{CM}$ & CGM1 & $\mathrm{HJ}$ \\
\hline Arginine & $93.35 \pm 0.92^{b}$ & $55.46 \pm 2.07^{c}$ & $248.98 \pm 26.13^{a}$ & $102.03 \pm 1.02^{b}$ & $60.69 \pm 0.71^{c}$ \\
\hline Ornithine & $4963.02 \pm 23.18^{c}$ & $6581.64 \pm 115.09^{a}$ & $3904.86 \pm 101.73^{d}$ & $4922.22 \pm 86.31^{c}$ & $5975.50 \pm 126.94^{b}$ \\
\hline
\end{tabular}

LAB isolates were incubated in de Man, Rogosa, and Sharpe (MRS) $+1.0 \%$ arginine at $30{ }^{\circ} \mathrm{C}$ for $48 \mathrm{~h}$, and then, arginine and ornithine contents were analyzed by HPLC. Values are the means \pm SDs of two independent cultivations. Means with different letters $(a-d)$ in the same row were significantly different $(p<0.05)$ as determined by Duncan's Multiple Range Test.

\subsection{Safety Assessment}

LAB are generally regarded as safe (GRAS), but it has been reported that some members of the genera Lactobacillus, Leuconostoc, Pediococcus, and Bifidobacterium can sometimes cause infections [31]. Because the health-promoting effects of LAB have led to their increased use in fermented foods, 
new LAB strains are continuously being sought for use as novel starter cultures or probiotics. However, new LAB strains require comprehensive testing to ensure they have no undesirable properties such as harmful biochemical effects, antibiotic resistance, or expressing virulence factors [10]. Thus, the efficacy of new LAB strains intended for use in starter cultures must be carefully assessed to determine their safety status. In this study, the new two LAB isolates, W. koreensis DB1 and HJ, were assessed for safety as follows.

\subsubsection{Undesirable Enzymatic Activities}

The enzymatic activities of selected $W$. koreensis DB1 and HJ were examined using an API-ZYM kit (Table 2). W. koreensis DB1 and HJ did not show undesirable enzyme activities, especially $\beta$-glucuronidase or $\alpha$-chymotrypsin activities, which have been reported to have negative effects in the colon [10]. $\beta$-Galactosidase hydrolyzes lactose to glucose and galactose, and W. koreensis DB1 showed $\beta$-galactosidase activity at $10 \mathrm{nmol}$. W. koreensis DB1 was determined to be lactose-negative in carbohydrate assimilation [32], which suggested W. koreensis DB1 has $\beta$-galactosidase but that its activity is too low to hydrolyze lactose completely. According to the manufacturer's instructions, the hydrolysis of $>20 \mathrm{nmol}$ of substrate is deemed positive. Thus, the two strains exhibited negative reactions to all the enzymes according to API-ZYM analysis.

Table 2. API-ZYM analysis of LAB enzyme activities.

\begin{tabular}{ccc}
\hline & \multicolumn{2}{c}{ Activity of $\mathbf{W}$. koreensis } \\
\cline { 2 - 3 } Enzyme (nmol) & DB1 & HJ \\
\hline Alkaline phosphate & 0 & 0 \\
Esterase (C4) & 0 & 0 \\
Esterase lipase (C8) & 0 & 0 \\
Lipase (C14) & 0 & 0 \\
Leucine arylamidase & 0 & 10 \\
Valine arylamidase & 0 & 0 \\
Cystine arylamidase & 0 & 0 \\
Trypsin & 0 & 0 \\
$\alpha$-Chymotrypsin & 0 & 0 \\
Acid phosphatase & 0 & 5 \\
A-Galactosidase & 5 & 5 \\
$\beta$-Galactosidase & 0 & 0 \\
$\beta$-Glucuronidase & 10 & 0 \\
$\alpha$-Glucosidase & 0 & 0 \\
$\beta$-Glucosidase & 0 & 0 \\
Naphthol-AS-BI-phosphohydrolase & 0 & 0 \\
$\alpha$-Mannosidase & 0 & 0 \\
$\alpha$-Fucosidase & 0 & 0 \\
N-Acetyl- $\beta$-glucosaminidase & 0 & 0 \\
\hline
\end{tabular}

Enzymatic activities are presented as nanomoles of hydrolyzed substrate after $4 \mathrm{~h}$ of incubation at $37^{\circ} \mathrm{C}$; $0=$ no activity, $5=5 \mathrm{nmol}$, and $10=10 \mathrm{nmol}$. According to the manufacturer's instructions, $\geq 20 \mathrm{nmol}$ of substrate hydrolyzed was defined as a positive reaction and $<20 \mathrm{nmol}$ of substrate hydrolyzed as a negative reaction.

\subsubsection{Antibiotic Resistance and Hemolysis}

Weissella species have not yet been granted Qualified Presumption of Safety (QPS) status by the European Commission's European Food Safety Authority [33], and thus, a breakpoint has not been recommended for the Weissella species. Weissella species are closely related to Leuconostoc species and were considered Leuconostoc species until the genus Weissella was proposed by Collins et al. based on $16 \mathrm{~S}$ rRNA phylogenetic analysis results [34]. Thus, the breakpoints for Leuconostoc species as stated by the EFSA and the MICs of other Weissella koreensis strains reported in the literature were used in this study. As shown in Table 3, the two LAB isolates had lower MICs than those highlighted for Leuconostoc by the EFSA. Furthermore, the MICs of the antibiotics tested were definitely lower than those reported 
for other Weissella koreensis strains [35,36]. Breakpoints of vancomycin for Leuconostoc species are not required by the technical guidelines of the EFSA [27], as Leuconostoc species are intrinsically vancomycin-resistant, unlike other general antibiotic resistance mechanisms [37]. The results in Table 3 show that $W$. koreensis DB1 and HJ are susceptible to all the antibiotics except vancomycin.

Table 3. Minimum inhibitory concentrations (MICs) of antibiotics for LAB.

\begin{tabular}{|c|c|c|c|c|}
\hline \multirow{2}{*}{$\begin{array}{l}\text { Antibiotics } \\
(\mu \mathrm{g} / \mathrm{mL})\end{array}$} & \multirow{2}{*}{$\begin{array}{l}\text { Breakpoints for } \\
\text { Leuconostocs }\end{array}$} & \multirow{2}{*}{$\begin{array}{c}\text { MICs for Other } \\
\text { Weissella koreensis }{ }^{2}\end{array}$} & \multicolumn{2}{|c|}{ W. koreensis } \\
\hline & & & DB1 & $\mathrm{HJ}$ \\
\hline Ampicillin & 2 & $1 \sim>10$ & 0.5 & 1 \\
\hline Vancomycin & N.R ${ }^{3}$ & 1024 & 512 & 512 \\
\hline Gentamycin & 16 & $>10-32$ & 2 & 4 \\
\hline Kanamycin & 16 & $30-512$ & 8 & 8 \\
\hline Streptomycin & 64 & 128 & 8 & 4 \\
\hline Erythromycin & 1 & $1 \sim>15$ & 0.06 & 0.25 \\
\hline Tetracycline & 8 & 1 & 0.5 & 0.5 \\
\hline Chloramphenicol & 4 & $4 \sim>30$ & 4 & 4 \\
\hline
\end{tabular}

$W$. koreensis DB1 and HJ did not show $\alpha$ - or $\beta$-hemolytic activities on horse blood agar in the hemolysis assays. However, Jeong and Lee have reported that two Weissella isolates from kimchi exhibited $\alpha$-hemolytic activity but no $\beta$-hemolysis [28].

\subsubsection{Biogenic Amine Production}

The enzymatic activities of $W$. koreensis DB1 and HJ can produce ornithine from arginine via the ADI pathway (Table 1). In particular, the biogenic amines (BAs) putrescine and agmatine can be produced by the microbial decarboxylation of ornithine and arginine [38]. We investigated whether the two isolates produce BAs via amino acid decarboxylation or via a combination of decarboxylation and the ADI pathway. The consumption of food containing high BAs is a risk for human health, as BAs have toxic effects [38]; it has been proposed that LAB starters lacking the ability to accumulate BA are needed to develop high-quality foods [15]. It has also been reported that some Weissella strains can produce BAs such as putrescine, tyramine, and histamine $[28,39]$. Thus, the two LAB were cultivated in MRS + $1.0 \%$ arginine for $48 \mathrm{~h}$, and then, the cultures were analyzed for BAs. As shown in Supplementary Figure S2, neither strain produced agmatine nor putrescine.

We believe it is reasonable to conclude that the consumption of $W$. koreensis DB1 and HJ does not represent a health risk based on the results of our safety assessment.

\subsection{Effects of Culture Conditions on LAB Growth}

\subsubsection{Effect of Temperature}

The highest cell growth in MRS broth was obtained at $30^{\circ} \mathrm{C}$, and this decreased progressively with temperature. The optimum growth temperature for $W$. koreensis DB1 and $\mathrm{HJ}$ was $30^{\circ} \mathrm{C}$, and they reached the stationary phase at 20-24 $\mathrm{h}$, with maximum cell viabilities of $8.85-8.86 \log \mathrm{CFU} / \mathrm{mL}$ in MRS broth. W. koreensis DB1 and HJ reached the stationary phase at 240 and $264 \mathrm{~h}$, respectively, when cultivated at $5{ }^{\circ} \mathrm{C}$ and showed $8.72-8.73 \log \mathrm{CFU} / \mathrm{mL}$ of viable cells (Figure 1). These results are consistent with a report that described that $W$. koreensis, a psychrophilic bacterium, grows well under mesophilic and psychrophilic conditions [15]. 

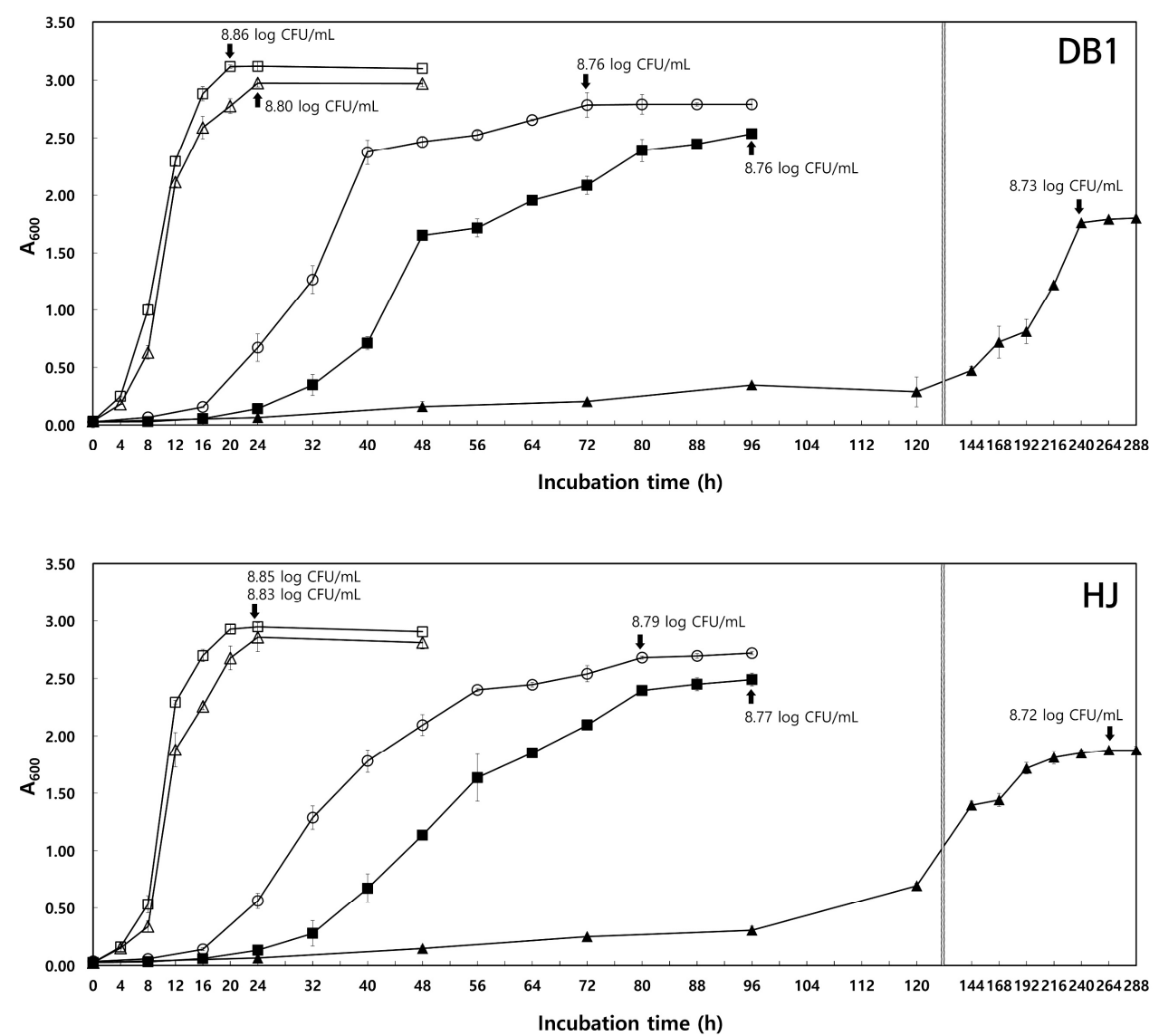

Figure 1. Growth of LAB at different temperatures. W. koreensis DB1 and HJ were incubated in MRS broth at $5{ }^{\circ} \mathrm{C}(\boldsymbol{\Delta}), 10^{\circ} \mathrm{C}(\boldsymbol{\square}), 15^{\circ} \mathrm{C}(\bigcirc), 25^{\circ} \mathrm{C}(\triangle)$, or $30^{\circ} \mathrm{C}(\square)$ for $24-288 \mathrm{~h}$.

\subsubsection{Effect of $\mathrm{pH}$}

W. koreensis DB1 and HJ were cultivated at $30^{\circ} \mathrm{C}$ for $24 \mathrm{~h}$ in MRS or MRS $+1.0 \%$ arginine medium adjusted to initial $\mathrm{pH}$ values of 5.0, 6.0, 7.0, or 8.0 (Figure 2). The cell growth of the two isolates was enhanced with arginine supplementation, but this growth enhancement was greater for W. koreensis DB1. It has been reported that supplementation with arginine enhances bacterial growth, as bacteria use arginine as an energy source via the ADI system [40]. W. koreensis DB1 showed the greatest cell growth at $\mathrm{pH} 5.0$ in MRS $+1.0 \%$ arginine and at $\mathrm{pH} 7.0-8.0$ in MRS. The reason for these different $\mathrm{pH}$ optima is presumed to be due to different amounts of $\mathrm{NH}_{3}$ being produced in MRS and MRS $+1.0 \%$ arginine cultures. That is, the $\mathrm{NH}_{3}$ produced via the ADI pathway in MRS $+1.0 \%$ arginine neutralizes the initial $\mathrm{pH}$ of 5.0 and the organic acids produced by glucose metabolism. The neutralizing effect of the $\mathrm{NH}_{3}$ produced by $W$. koreensis DB1 in MRS + arginine might also aid bacterial growth in culture. On the other hand, $W$. koreensis DB1 cultured in MRS produced organic acids but not $\mathrm{NH}_{3}$, and thus, an initial $\mathrm{pH}$ of 5.0 in MRS inhibited the growth.

On the other hand, $W$. koreensis $\mathrm{HJ}$ showed the lowest cell growth at $\mathrm{pH} 5.0$ and highest cell growth at $\mathrm{pH} 7.0-8.0$ in MRS and at $\mathrm{pH} 6.0-8.0$ in MRS $+1.0 \%$ arginine. W. koreensis $\mathrm{HJ}$ can also degrade arginine via the ADI pathway and produce $\mathrm{NH}_{3}$, but it appears that the arginine catabolic ability of $W$. koreensis $\mathrm{HJ}$ was not enough to neutralize the initial $\mathrm{pH}$ of 5.0 and the organic acids produced when it was cultured in MRS + arginine. These results imply that the ornithine-producing capacity of $W$. koreensis DB1 is greater than that of W. koreensis HJ, which is in line with the results shown in Table 1.

Based on the results shown in Figure 2, we concluded that the optimum initial $\mathrm{pH}$ for $W$. koreensis $\mathrm{DB} 1$ in MRS $+1.0 \%$ arginine was 5.0, whereas that for $W$. koreensis $\mathrm{HJ}$ was 8.0, because $W$. koreensis $\mathrm{HJ}$ 
had a slightly higher viable cell count at $\mathrm{pH} 8.0$ (7.93 $\log \mathrm{CFU} / \mathrm{mL}$ at $\mathrm{pH} 6.0$ and $8.36 \log \mathrm{CFU} / \mathrm{mL}$ at $\mathrm{pH} 8.0$ in MRS + $1.0 \%$ arginine).
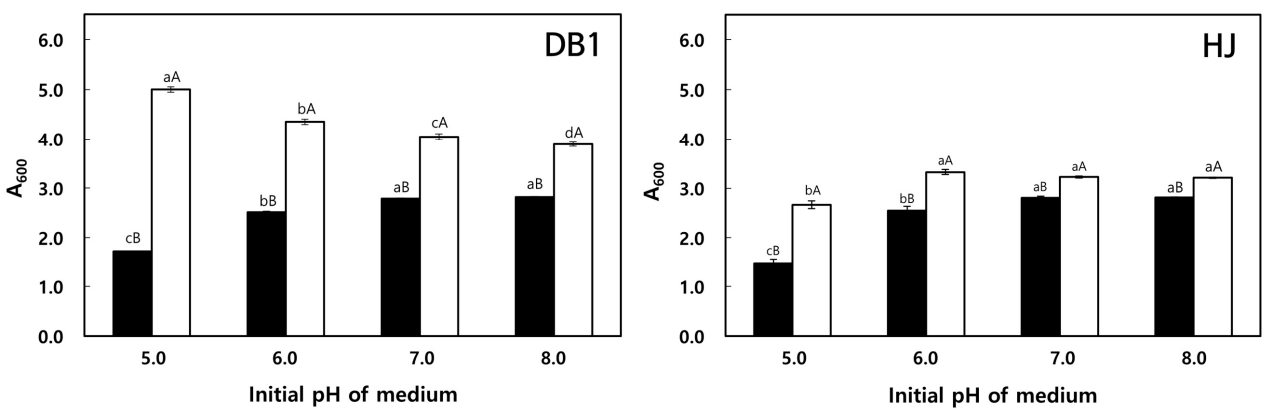

Figure 2. Effect of initial $\mathrm{pH}$ on LAB growth. Initial $\mathrm{pH}$ values of MRS (घ) and MRS $+1.0 \%$ arginine ( $\square$ ) were adjusted to 5.0-8.0, and then, W. koreensis DB1 or HJ were cultivated in these media for $24 \mathrm{~h}$ at $30{ }^{\circ} \mathrm{C}$. Different lowercase letters indicate significant differences $(p<0.05)$ between cultures with different initial $\mathrm{pH}$ values as determined by Duncan's multiple range test. Different uppercase letters indicate significant differences $(p<0.05)$ between cultures with or without arginine supplementation as determined by the independent-samples $t$ test.

\subsubsection{Effect of Arginine Concentration}

When $W$. koreensis DB1 and HJ were cultivated in MRS supplemented with 0.5-3.0\% arginine without $\mathrm{pH}$ adjustment, the isolate growth was obviously low (Figure 3-left side). In particular, in the presence of 2.0-3.0\% arginine, little growth was observed for 24-48 h. However, when the $\mathrm{pH}$ values were adjusted to $\mathrm{pH} 5.0$ for $W$. koreensis DB1 and $\mathrm{pH} 8.0$ for W. koreensis HJ, cell growth was significantly improved, especially in MRS supplemented with 1.0-3.0\% arginine (Figure 3-right side).
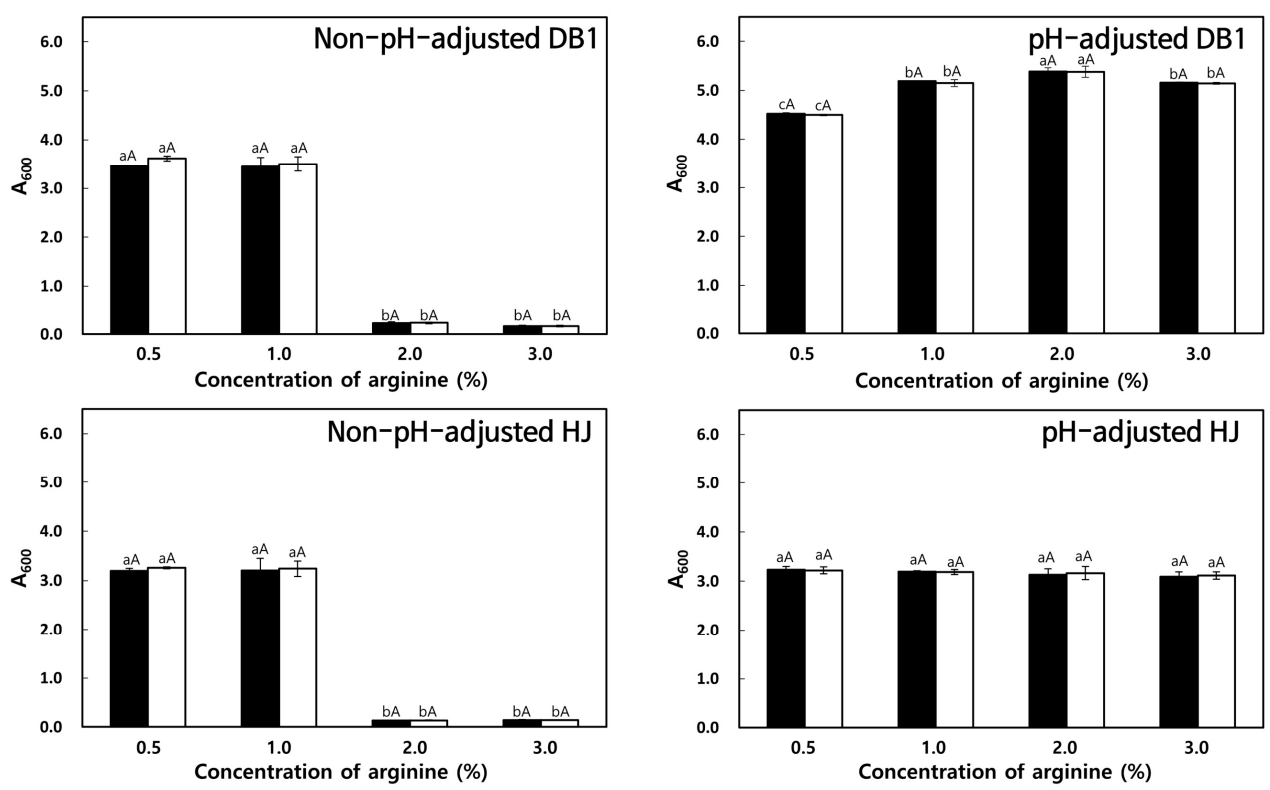

Figure 3. Effect of arginine concentration in MRS on LAB growth. W. koreensis DB1 and W. koreensis $\mathrm{HJ}$ were cultivated in non-pH-adjusted (left side) or $\mathrm{pH}$-adjusted (right side; $\mathrm{pH} 5.0$ for W. koreensis DB1 and pH 8.0 for $W$. koreensis HJ) MRS $+1.0 \%$ arginine for $24 \mathrm{~h}(\boldsymbol{\square})$ or $48 \mathrm{~h}(\square)$ at $30{ }^{\circ} \mathrm{C}$. Different lowercase letters indicate significant differences $(p<0.05)$ between cultures with different arginine concentrations as determined by Duncan's multiple range test. Different uppercase letters indicate significant differences $(p<0.05)$ between cultivation times as determined by the independent-samples $t$ test. 
Ornithine production by $W$. koreensis DB1 in MRS supplemented with 1.0-3.0\% arginine for 24- $48 \mathrm{~h}$ (adjusted to an initial $\mathrm{pH}$ of 5.0) at $30^{\circ} \mathrm{C}$ was quantified by HPLC (Figure 4). The highest ornithine $(15,059.65 \mathrm{mg} / \mathrm{L})$ and citrulline $(6206.03 \mathrm{mg} / \mathrm{L})$ production with $97.17 \%$ arginine conversion was obtained for $3.0 \%$ arginine supplementation and cultivation for $48 \mathrm{~h}$, whereas the lowest ornithine $(8697.99 \mathrm{mg} / \mathrm{L})$ and citrulline $(38.23 \mathrm{mg} / \mathrm{L})$ production was obtained with a $99.83 \%$ conversion of arginine for $1.0 \%$ arginine supplementation and cultivation for $24 \mathrm{~h}$. Arginine is degraded by the ADI pathway into citrulline, ornithine, $\mathrm{CO}_{2}$, and $\mathrm{NH}_{3}$ [15]. The supplemented arginine (1.0-3.0\%) levels rapidly decreased, and arginine was mainly converted to ornithine, for $24 \mathrm{~h}$. Citrulline was also produced as a metabolic intermediate and accumulated when arginine was supplemented at levels $>2.0 \%$.
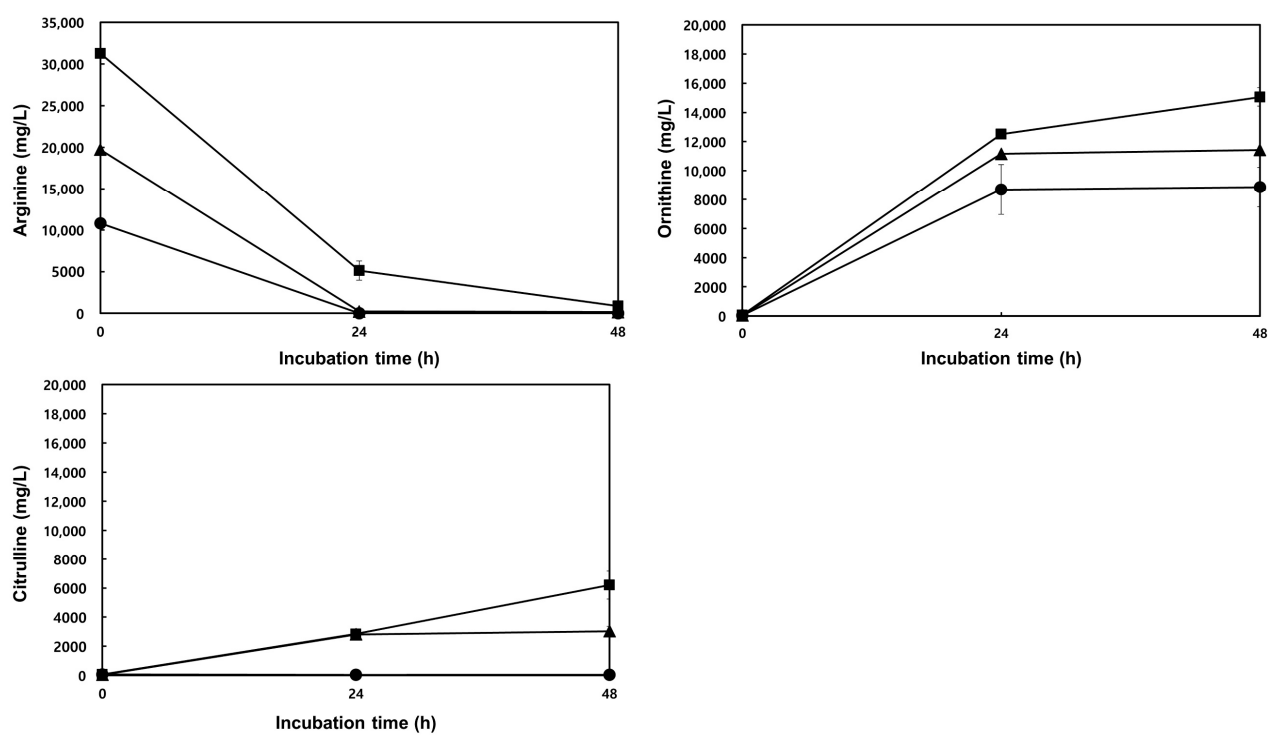

Figure 4. Ornithine and citrulline production by W. koreensis DB1. W. koreensis DB1 was cultivated in MRS broth supplemented with $1.0 \%(\bullet), 2.0 \%(\boldsymbol{\Lambda})$, or $3.0 \%(\boldsymbol{\square})$ arginine (initial $\mathrm{pH}, 5.0$ ) at $30{ }^{\circ} \mathrm{C}$ for 24-48 h. Levels of arginine, citrulline, and ornithine in cultures were determined by HPLC as described in Materials and Methods.

\subsection{Characteristics of the Fermented Rice Bran}

\subsubsection{LAB Growth and Ornithine Production}

High cell growth is one of the important factors for producing ornithine. $W$. koreensis DB1 was cultured in $20 \%$ rice bran $+1.0 \%$ arginine supplemented with $1.0-3.0 \%$ glucose and $1.0-5.0 \%$ corn steep liquor at $30^{\circ} \mathrm{C}$ for $48 \mathrm{~h}$, and then, cell growth was determined. As shown in Supplementary Table S2, the highest cell growth was obtained from the addition of $2.0 \%$ glucose and $3.0 \%$ corn steep liquor. Based on the results of Supplementary Table S2, we prepared rice bran slurries composed of $20 \%$ rice bran $+2.0 \%$ glucose $+3.0 \%$ corn steep liquor supplemented with $1.0 \%(\mathrm{~A}), 2.0 \%(\mathrm{~B})$, or $3.0 \%$ (C) arginine in distilled water. The slurries were autoclaved $\left(121^{\circ} \mathrm{C}, 15 \mathrm{~min}\right)$, and then, $W$. koreensis DB1 was inoculated (at $\sim 6 \log \mathrm{CFU} / \mathrm{mL}$ ). When the initial $\mathrm{pH}$ of the slurries was adjusted to 5.0 (based on the results shown in Figure 2), no W. koreensis DB1 growth was observed, which indicated that an initial pH of 5.0 was unsuitable for $W$. koreensis DB1 cultivation. This is presumably due to differences between the nutritional compositions of MRS and rice bran slurries. Actually, the optimum $\mathrm{pH}$ for the growth of most LAB is 6.0-7.0 [41], and thus, the initial pH of the commercialized MRS (Difco, Sparks, MD, USA) is pH $6.5 \pm 0.2$. The composition of MRS is optimized for LAB growth. In MRS + arginine (even though its initial $\mathrm{pH}$ was adjusted to $\mathrm{pH} 5.0$ ), rapid cell growth occurred, and consequently, the $\mathrm{NH}_{3}$ produced neutralized the initial acidity and enhanced cell growth (Figure 2). However, the rice bran 
slurry used in the present study was not a growth medium optimized for LAB, and this probably inhibited W. koreensis DB1 growth with an initial $\mathrm{pH}$ of 5.0.

When the initial $\mathrm{pH}$ of the rice bran slurry was adjusted to $\mathrm{pH} 6.0$ and the slurry was then fermented at $30^{\circ} \mathrm{C}$ for $48 \mathrm{~h}, W$. koreensis DB1 grew well, and this resulted in almost the same viable cell count as cultivation in MRS $+1.0 \%$ arginine ( $\mathrm{pH}$ 6.0, $8.58 \log \mathrm{CFU} / \mathrm{mL})$. W. koreensis DB1 growth in rice bran slurry reached $8.61-8.72 \log \mathrm{CFU} / \mathrm{mL}$ after $48 \mathrm{~h}$ of fermentation, and the resultant $\mathrm{pH}$ values were 5.54 for $\mathrm{A}, 6.37$ for $\mathrm{B}$, and 7.16 for $\mathrm{C}$ (Table 4). Thus, the final $\mathrm{pH}$ values of the fermented rice bran increased with the initial arginine concentration, which suggests that higher initial arginine concentrations resulted in greater arginine catabolism by W. koreensis DB1 (Table 4). Lactic and acetic acids were detected at $16,253.65$ and $1723.24 \mathrm{mg} / \mathrm{kg}$, respectively, at $0 \mathrm{~h}$ due to the addition of $3.0 \%$ corn steep liquor, which contains both. After $48 \mathrm{~h}$ of fermentation, the highest organic acid concentration (lactic and acetic acids; $60,952.93 \mathrm{mg} / \mathrm{kg}$ ) was detected for A and the lowest organic acid concentration $(50,068.36 \mathrm{mg} / \mathrm{kg})$ was detected for $\mathrm{C}$, which was consistent with the $\mathrm{pH}$ results.

Table 4. $\mathrm{pH}$, viable cell, and amino acid content changes in fermented rice bran.

\begin{tabular}{|c|c|c|c|}
\hline \multirow{2}{*}{ Fermented Rice Bran } & \multirow{2}{*}{ Characteristics } & \multicolumn{2}{|c|}{ Fermentation time } \\
\hline & & $\mathbf{O h}$ & $48 \mathrm{~h}$ \\
\hline \multirow{7}{*}{ A } & $\mathrm{pH}$ & $6.00 \pm 0.01^{a}$ & $5.54 \pm 0.20^{b}$ \\
\hline & Viable cells $(\log \mathrm{CFU} / \mathrm{mL})$ & $6.07 \pm 0.12^{b}$ & $8.61 \pm 0.09^{a}$ \\
\hline & Arginine (mg/kg) & $27,986.04 \pm 279.01^{\mathrm{a}}$ & $169.33 \pm 82.95^{b}$ \\
\hline & Citrulline (mg/kg) & $74.10 \pm 9.10^{\mathrm{b}}$ & $5444.79 \pm 364.49^{\mathrm{a}}$ \\
\hline & Ornithine (mg/kg) & $17.10 \pm 2.10^{b}$ & $19,972.33 \pm 1255.01^{a}$ \\
\hline & Lactic acid (mg/kg) & $16,253.65 \pm 477.16^{b}$ & $58,743.83 \pm 673.83^{a}$ \\
\hline & Acetic acid $(\mathrm{mg} / \mathrm{kg})$ & $1723.24 \pm 50.59^{b}$ & $2209.00 \pm 25.34^{\mathrm{a}}$ \\
\hline \multirow{7}{*}{ B } & $\mathrm{pH}$ & $6.00 \pm 0.01^{b}$ & $6.37 \pm 0.02^{\mathrm{a}}$ \\
\hline & Viable cells $(\log \mathrm{CFU} / \mathrm{mL})$ & $6.06 \pm 0.06^{b}$ & $8.72 \pm 0.15^{\mathrm{a}}$ \\
\hline & Arginine $(\mathrm{mg} / \mathrm{kg})$ & $64,950.08 \pm 425.02^{\mathrm{a}}$ & $256.26 \pm 25.79^{b}$ \\
\hline & Citrulline (mg/kg) & $127.23 \pm 6.90^{\mathrm{b}}$ & $16,113.25 \pm 2321.96^{\mathrm{a}}$ \\
\hline & Ornithine $(\mathrm{mg} / \mathrm{kg})$ & $68.02 \pm 7.03^{b}$ & $32,747.80 \pm 1421.15^{a}$ \\
\hline & Lactic acid (mg/kg) & $16,253.65 \pm 477.16^{b}$ & $52,493.50 \pm 1100.15^{a}$ \\
\hline & Acetic acid $(\mathrm{mg} / \mathrm{kg})$ & $1723.24 \pm 50.59^{b}$ & $3736.31 \pm 1113.09^{\mathrm{a}}$ \\
\hline \multirow{7}{*}{$\mathrm{C}$} & $\mathrm{pH}$ & $6.00 \pm 0.00^{b}$ & $7.16 \pm 0.10^{\mathrm{a}}$ \\
\hline & Viable cells $(\log \mathrm{CFU} / \mathrm{mL})$ & $6.07 \pm 0.09^{b}$ & $8.65 \pm 0.10^{\mathrm{a}}$ \\
\hline & Arginine $(\mathrm{mg} / \mathrm{kg})$ & $91,813.04 \pm 608.01^{\mathrm{a}}$ & $464.14 \pm 33.94^{b}$ \\
\hline & Citrulline $(\mathrm{mg} / \mathrm{kg})$ & $188.07 \pm 8.05^{b}$ & $27,336.37 \pm 4870.86^{\mathrm{a}}$ \\
\hline & Ornithine (mg/kg) & $442.10 \pm 55.06^{b}$ & $43,074.13 \pm 2457.05^{a}$ \\
\hline & Lactic acid (mg/kg) & $16,253.65 \pm 477.16^{b}$ & $45,380.99 \pm 1258.69^{a}$ \\
\hline & Acetic acid (mg/kg) & $1723.24 \pm 50.59^{b}$ & $4687.37 \pm 183.08^{\mathrm{a}}$ \\
\hline
\end{tabular}

Rice bran slurry was composed of $20 \%$ rice bran powder $+2.0 \%$ glucose $+3.0 \%$ corn steep liquor supplemented with $1.0 \%(\mathrm{~A}), 2.0 \%(\mathrm{~B})$, or $3.0 \%(\mathrm{C})$ arginine in distilled water. The slurry was autoclaved $\left(121^{\circ} \mathrm{C}, 15 \mathrm{~min}\right)$, and $\mathrm{W}$. koreensis DB1 was inoculated $(\sim 6 \log \mathrm{CFU} / \mathrm{mL})$ and used for fermentation at $30^{\circ} \mathrm{C}$ for $48 \mathrm{~h}$. pH and viable cell counts were then determined. The fermented rice bran slurry ( 0 or $48 \mathrm{~h}$ ) was freeze-dried and then ground, and amino acid contents were analyzed by HPLC. Values are the means \pm SDs of three independent cultivations. Means with different letters $(a-b)$ in the same row were significantly different $(p<0.05)$ as determined by the Independent Samples $T$ Test.

In fact, $99.39-99.61 \%$ of the arginine supplemented at 1.0-3.0\% was consumed by the production of ornithine, citrulline, and other ADI metabolites. The highest ornithine yield $(43,074.13 \mathrm{mg} / \mathrm{kg})$ was obtained for rice bran fermentation supplemented with 3.0\% arginine, which also resulted in a citrulline yield of $27,336.37 \mathrm{mg} / \mathrm{kg}$. In our previous preliminary study, rice bran was fermented under non-optimized fermentation conditions. In detail, rice bran slurries were prepared with $20 \%$ rice bran $+1.0 \%$ glucose $+1.0 \%$ arginine without $\mathrm{pH}$ adjustment in distilled water. The $\mathrm{pH}$ of the prepared rice bran was 6.84 due to arginine addition. W. koreensis DB1 was inoculated (at $6 \log \mathrm{CFU} / \mathrm{mL}$ ) and used for fermentation for $48 \mathrm{~h}$ at $30^{\circ} \mathrm{C}$. After fermentation, the $\mathrm{pH}$ of the fermented rice bran was $\mathrm{pH}$ 6.61, and viable cells were detected at $8.15 \log \mathrm{CFU} / \mathrm{mL}$. Thereafter, the fermented rice bran was hot-air dried at $55^{\circ} \mathrm{C}$ for $12 \mathrm{~h}$, and then, the ornithine and citrulline contents were determined at 8446.78 and 3199.46 
$\mathrm{mg} / \mathrm{kg}$, respectively [25]. However, the amount of ornithine produced was not enough to satisfy daily requirements for functional food; thus, the enhancement of ornithine in fermented rice bran was needed. Based on the results of our previous study and the results presented in this study, glucose, corn steep liquor, and arginine were added in rice bran fermentation. The addition of $2.0 \%$ glucose, $3.0 \%$ corn steep liquor, and $3.0 \%$ arginine in $20 \%$ rice bran slurry (the initial $\mathrm{pH}$ was adjusted to $\mathrm{pH} 6.0$ ) clearly increased $W$. koreensis DB1 growth and ornithine production. The differences between the previous study and this study in terms of rice bran fermentation conditions were $\mathrm{pH}$ adjustment (to $\mathrm{pH}$ 6.0) and the rice bran slurry composition, namely, with respect to glucose, corn steep liquor, and arginine. After changing the fermentation conditions, the ornithine and citrulline contents were significantly greater than those observed during the previous study. L-ornithine has a variety of beneficial effects, such as stress reduction, physical fatigue reduction, anti-obesity effects, and others [15]. When used as a dietary supplement, L-citrulline appears to be a powerful pharmaconutrient that reduces hypertension, arterial stiffness, and lipid oxidation, and increases muscle mass, muscle performance, and fat-free mass [42]. Citrulline is almost absent in foods. Actually, only watermelons contain significant amounts of citrulline [42]. L-citrulline has been reported to provide an efficient intervention for increasing L-arginine bioavailability [43]. We found that $W$. koreensis DB1-fermented rice bran resulted in the production of high levels of ornithine $(43,074.13 \mathrm{mg} / \mathrm{L})$ and citrulline $(27,336.37 \mathrm{mg} / \mathrm{L})$.

\subsubsection{Sensory Evaluation}

On performing a sensory evaluation as shown in Table 5, the fermented rice bran (FRB) showed a superior taste and flavor along with a soft mouthfeel. The FRB clearly received higher scores for overall preference than the others. The FRB presented its own characteristic balanced combination of savory flavor and moderately salty taste along with a soft mouthfeel texture. The savory flavor may have stemmed from the fermentative characteristics of $W$. koreensis DB1 and the moderately salty taste resulting from the neutralization of lactic acid by the ammonia produced by $W$. koreensis DB1.

Table 5. Sensory evaluation of fermented rice bran.

\begin{tabular}{cccc}
\hline Items & RRB & SRB & FRB \\
\hline Bitterness & $3.8 \pm 0.8^{\mathrm{a}}$ & $1.8 \pm 0.4^{\mathrm{b}}$ & $3.5 \pm 0.8^{\mathrm{a}}$ \\
Saltiness & $1.9 \pm 0.7^{\mathrm{b}}$ & $3.5 \pm 0.8^{\mathrm{a}}$ & $3.8 \pm 0.4^{\mathrm{a}}$ \\
Savory flavor & $2.3 \pm 0.9^{\mathrm{c}}$ & $3.3 \pm 0.6^{\mathrm{b}}$ & $4.5 \pm 0.5^{\mathrm{a}}$ \\
Hay smell & $1.5 \pm 0.5^{\mathrm{c}}$ & $3.6 \pm 0.5^{\mathrm{b}}$ & $4.2 \pm 0.6^{\mathrm{a}}$ \\
Mouthfeel texture & $1.7 \pm 0.5^{\mathrm{c}}$ & $3.7 \pm 0.8^{\mathrm{b}}$ & $4.3 \pm 0.5^{\mathrm{a}}$ \\
Overall acceptability & $1.7 \pm 0.5^{\mathrm{c}}$ & $2.8 \pm 0.8^{\mathrm{b}}$ & $4.4 \pm 0.5^{\mathrm{a}}$ \\
\hline
\end{tabular}

Rice bran slurry was composed of $20 \%$ raw rice bran powder (RRB) supplemented with $2.0 \%$ glucose, $3.0 \%$ corn steep liquor, and $3.0 \%$ arginine in distilled water. The slurry was autoclaved, and then, $W$. koreensis DB1 was inoculated $(\sim 6 \log \mathrm{CFU} / \mathrm{mL})$; the slurry was then fermented at $30^{\circ} \mathrm{C}$ for $0 \mathrm{~h}$ (SRB) or for $48 \mathrm{~h}$ (FRB), freeze-dried, and ground. Sensory evaluation was carried out using the prepared RRB, SRB, and FRB samples and rated using a 5 -point scale, in which 1, 3, and 5 corresponded to very bad, moderate, and very good, respectively. Values are the means \pm SDs of duplicate determinations. Means with different letters $(a-c)$ in the same row were significant differences $(p<0.05)$, as determined by Duncan's Multiple Range Test.

Generally, rice bran addition in food products has an unacceptable effect due to its typical smell and texture [44]. However, our results indicated that the sensory quality of rice bran was substantially improved via $W$. koreensis DB1 fermentation. Raw rice bran (RRB) smells of hay and has a coarse mouthfeel and bland taste, and freeze-dried rice bran slurry without fermentation (SRB) is bitter due to the presence of arginine [45]. However, the bitterness of SRB and the hay-like smell and coarse texture of RRB were clearly removed by fermentation.

\section{Conclusions}

Rice bran is a by-product of rice polishing and is a rich source of dietary fiber (11.77-12.68\%) [46]. The consumption of dietary fiber has beneficial effects on human health, as it ameliorates gastrointestinal 
concerns, improves lipid metabolism, and reduces cholesterol levels [46,47]. In addition, rice bran has prebiotic properties $[47,48]$. Consumers are ever more interested in the health-promoting attributes of food and their organoleptic properties. In this study, high-ornithine-producing W. koreensis DB1 isolated from kimchi was used as a starter culture for rice bran fermentation. Our results showed W. koreensis DB1 did not exhibit any harmful characteristics, and we concluded that $W$. koreensis DB1 is suitable as a safe starter culture for the development of high-quality foods. Compared to the results of the previous study, this study reports significant increases in ornithine and citrulline contents under optimal rice bran fermentation conditions for $W$. koreensis DB1. Ten grams of W. koreensis DB1-fermented rice bran was found to contain sufficient ornithine $(43,074.13 \mathrm{mg} / \mathrm{kg})$ to satisfy daily requirements (400-1000 mg). It also contained around $27,336.37 \mathrm{mg} / \mathrm{kg}$ of citrulline and viable LAB W. koreensis DB1 (8.65 $\log$ CFU/mL), and was rich in dietary fiber. Moreover, fermented rice bran showed substantially improved organoleptic quality. These results indicate that the fermented rice bran produced during this study is a promising functional food candidate with excellent composition, functionality, and organoleptic quality. The health beneficial effects of the fermented rice bran produced will be confirmed by further pre-clinical trials in animals and clinical trials in human subjects.

Supplementary Materials: The following are available online at http://www.mdpi.com/2304-8158/9/11/1545/s1 . Figure S1: RAPD patterns of LAB. Bands distinctly distinct among LAB strains are marked with red boxes. LAB strains displaying different RAPD patterns after annealing at different temperatures are indicated as (1)-(5), Figure S2: HPLC chromatogram of biogenic amines. Biogenic amine standards: PUT, putrescine; HIS, histamine; AGM, agmatine; and IS, 1,7-diaminoheptane (the internal standard) (A). Culture supernatant of W. koreensis DB1 (B). Culture supernatant of W. koreensis HJ (C). Figure S3: TLC analysis of LAB cultures. W. koreensis DB1 and W. koreensis $\mathrm{HJ}$ were incubated in MRS broth supplemented with 0.5-3.0\% arginine for $24 \mathrm{~h}$ (A) or $48 \mathrm{~h}$ (B). Cultures were then analyzed by TLC as described in Materials and Methods. 1: arginine standard, 2: ornithine standard, 3-6: initial pHs of the cultures were adjusted to $\mathrm{pH} 5.0$ for DB1 and to $\mathrm{pH} 8.0$ for $\mathrm{HJ}$, and 7-10: $\mathrm{pHs}$ of cultures were not adjusted (controls). Table S1: Similarities of the 16S rRNA gene sequences of LAB isolates with those in the GenBank database. Table S2: Viable cell determination according to addition of corn steep liquor and glucose in rice bran fermentation.

Author Contributions: Conceptualization, C.H.C.; funding acquisition, C.H.C.; investigation, M.S.Y. and M.S.H.; project administration, C.H.C.; supervision, C.H.C.; validation, M.S.Y. and M.S.H.; visualization, M.S.Y. and M.S.H.; writing - original draft, C.H.C.; writing - review and editing, C.H.C. All authors have read and agreed to the published version of the manuscript.

Funding: This research was funded by the Ministry of Agriculture, Food and Rural Affairs, Republic of Korea, grant number 918005-4.

Acknowledgments: This research was supported by the Strategic Initiative for Microbiomes in Agriculture and Food, Ministry of Agriculture, Food and Rural Affairs, Republic of Korea. The grant number is 918005-4.

Conflicts of Interest: The authors declare no conflict of interest.

\section{References}

1. Rakhimuzzaman, M.; Noda, M.; Danshiitsoodol, N.; Sugiyama, M. Development of a system of high ornithine and citrulline production by a plant-derived lactic acid bacterium, Weissella confusa K-28. Biol. Pharm. Bull. 2019, 42, 1581-1589. [CrossRef] [PubMed]

2. Miyake, M.; Kirisako, T.; Kokubo, T.; Miura, Y.; Morishita, K.; Okamura, H.; Tsuda, A. Randomised controlled trial of the effects of L-ornithine on stress markers and sleep quality in healthy workers. Nutr. J. 2014, 13, 53. [CrossRef] [PubMed]

3. Konishi, Y.; Koosaka, Y.; Maruyama, R.; Imanishi, K.; Kasahara, K.; Matsuda, A.; Akiduki, S.; Hishida, Y.; Kurata, Y.; Shibamoto, T.; et al. L-Ornithine intake affects sympathetic nerve outflows and reduces body weight and food intake in rats. Brain Res. Bull. 2015, 111, 48-52. [CrossRef] [PubMed]

4. Kurata, K.; Nagasawa, M.; Tomonaga, S.; Aoki, M.; Akiduki, S.; Morishita, K.; Denbow, D.M.; Furuse, M. Orally administered L-ornithine reduces restraint stress-induced activation of the hypothalamic-pituitary-adrenal axis in mice. Neurosci. Lett. 2012, 506, 287-291. [CrossRef] [PubMed]

5. Shi, H.P.; Fishel, R.S.; Efron, D.T.; Williams, J.Z.; Fishel, M.H.; Barbul, A. Effect of supplemental ornithine on wound healing. J. Surg. Res. 2002, 106, 299-302. [CrossRef] 
6. Yu, J.J.; Oh, S.H. Isolation and characterization of lactic acid bacteria strains with ornithine producing capacity from natural sea salt. J. Microbiol. 2010, 48, 467-472. [CrossRef]

7. Uchisawa, H.; Sato, A.; Ichita, J.; Matsue, H.; Ono, T. Influence of low-temperature processing of the brackish-water bivalve, Corbicula japonica, on the ornithine content of its extract. Biosci. Biotechnol. Biochem. 2004, 68, 1228-1234. [CrossRef]

8. Sugino, T.; Shirai, T.; Kajimoto, Y.; Kajimoto, O. L-ornithine supplementation attenuates physical fatigue in healthy volunteers by modulating lipid and amino acid metabolism. Nutr. Res. 2008, 28, 738-743. [CrossRef] [PubMed]

9. Choi, E.A.; Chang, H.C. Cholesterol-lowering effects of a putative probiotic strain Lactobacillus plantarum EM isolated from kimchi. LWT Food. Sci. Technol. 2015, 62, 210-217. [CrossRef]

10. Ryu, E.H.; Chang, H.C. In vitro study of potentially probiotic lactic acid bacteria strains isolated from kimchi. Ann. Microbiol. 2013, 63, 1387-1395. [CrossRef]

11. Ryu, E.H.; Yang, E.J.; Woo, E.R.; Chang, H.C. Purification and characterization of antifungal compounds from Lactobacillus plantarum HD1 isolated from kimchi. Food Microbiol. 2014, 41, 19-26. [CrossRef]

12. Jo, S.Y.; Choi, E.A.; Lee, J.J.; Chang, H.C. Characterization of starter kimchi fermented with Leuconostoc kimchii GJ2 and its cholesterol-lowering effects in rats fed a high-fat and high-cholesterol diet. J. Sci. Food Agrc. 2015, 95, 2750-2756. [CrossRef]

13. Lee, S.H.; Chang, H.C. Isolation of antifungal activity of Leuconostoc mesenteroides TA from kimchi and characterization of its antifungal compounds. Food Sci. Biotechnol. 2016, 25, 213-219. [CrossRef] [PubMed]

14. Jeon, Y.B.; Lee, J.J.; Chang, H.C. Characterization of juice fermented with Lactobacillus plantarum EM and its cholesterol-lowering effects on rats fed a high-fat and high-cholesterol diet. Food Sci. Nutr. 2019, 7, 3622-3634. [CrossRef]

15. Mun, S.Y.; Chang, H.C. Characterization of Weissella koreensis SK isolated from kimchi fermented at low temperature (around $0{ }^{\circ} \mathrm{C}$ ) based on complete genome sequence and corresponding phenotype. Microorganisms 2020, 8, 1147. [CrossRef]

16. Arena, M.E.; Saguir, F.M.; De Nadra, M.M. Arginine, citrulline and ornithine metabolism by lactic acid bacteria from wine. Int. J. Food Microbiol. 1999, 52, 155-161. [CrossRef]

17. Hwang, H.; Lee, J.H. Characterization of arginine catabolism by lactic acid bacteria isolated from kimchi. Molecules 2018, 23, 3049. [CrossRef] [PubMed]

18. Moon, S.H.; Kim, C.R.; Lee, P.W.; Chang, H.C. Study on the establishment of standard for mukeunji product through characteristic analysis of commercial mukeunji products. Korean J. Community Living Sci. 2019, 30, 33-51. [CrossRef]

19. Lee, H.H.; Kim, G.H. Changes in the levels of $\gamma$-aminobutyric acid and free amino acids during kimchi fermentation. Korean J. Food Cook. Sci. 2013, 29, 671-677. [CrossRef]

20. Yang, E.J.; Chang, H.C. Antifungal activity of Lactobacillus plantarum isolated from kimchi. Microbiol. Biotechnol. Lett. 2008, 36, 276-284.

21. Padonou, S.W.; Schillinger, U.; Nielsen, D.S.; Franz, C.M.; Hansen, M.; Hounhouigan, J.D.; Nago, M.C.; Jakobsen, M. Weissella beninensis sp. nov., a motile lactic acid bacterium from submerged cassava fermentations, and emended description of the genus Weissella. Int. J. Syst. Evol. Microbiol. 2010, 60, 2193-2198. [CrossRef]

22. Kang, E.S.; Ford, K.; Grokulsky, G.; Wang, Y.B.; Chiang, T.M.; Acchiardo, S.R. Normal circulating adult human red blood cells contain inactive NOS proteins. J. Lab. Clin. Med. 2000, 135, 444-451. [CrossRef] [PubMed]

23. Cho, Y.R.; Chang, J.Y.; Chang, H.C. Production of gamma-aminobutyric acid (GABA) by Lactobacillus buchneri isolated from kimchi and its neuroprotective effect on neuronal cells. J. Microbiol. Biotechnol. 2007, 17, 104-109. [PubMed]

24. Henderson, J.W.; Ricker, R.D.; Bidlingmeyer, B.A.; Woodward, C. Rapid, accurate, sensitive, and reproducible HPLC analysis of amino acids. Agil. Appl. Note 2000, 1100, 1-10.

25. Moon, S.H.; Mun, S.Y.; Chang, H.C. Characterization of fermented rice-bran using the lactic acid bacteria Weissella koreensis DB1 derived from kimchi. Korean J. Community Living Sci. 2019, 30, 543-551. [CrossRef] 
26. Moon, S.H.; Kim, C.R.; Chang, H.C. Heterofermentative lactic acid bacteria as a starter culture to control kimchi fermentation. LWT Food Sci. Technol. 2018, 88, 181-188. [CrossRef]

27. European Food Safety Authority (EFSA). Guidance on the assessment of bacterial susceptibility to antimicrobials of human and veterinary importance. EFSA J. 2012, 10, 2740.

28. Jeong, D.W.; Lee, J.H. Antibiotic resistance, hemolysis and biogenic amine production assessments of Leuconostoc and Weissella isolates for kimchi starter development. LWT Food. Sci. Technol. 2015, 64, 1078-1084. [CrossRef]

29. Özdestan, Ö.; Üren, A. A method for benzoyl chloride derivatization of biogenic amines for high performance liquid chromatography. Talanta 2009, 78, 1321-1326. [CrossRef]

30. Chang, M.; Chang, H.C. Development of a screening method for biogenic amine producing Bacillus spp. Int. J. Food Microbiol. 2012, 153, 269-274. [CrossRef]

31. Liong, M.T. Safety of probiotics: Translocation and infection. Nut. Rev. 2008, 66, 192-202. [CrossRef] [PubMed]

32. Chang, H.C.; Moon, S.H.; Mun, S.Y.; Lee, J.J. Method for Preparing Fermented Rice Bran by Using Weissella koreensis and Fermented Rice Bran Prepared Thereby. K. R. Patent 10-2019-0131979, 23 October 2019.

33. European Food Safety Authority (EFSA). Update of the list of QPS-recommended biological agents intentionally added to food or feed as notified to EFSA 10: Suitability of taxonomic units notified to EFSA until March 2019. EFSA J. 2019, 17, 5753.

34. Collins, M.D.; Samelis, J.; Metaxopoulos, J.; Wallbanks, S. Taxonomic studies on some leuconostoc-like organisms from fermented sausages: Description of a new genus Weissella for the Leuconostoc paramesenteroides group of species. J. Appl. Bacteriol. 1993, 75, 595-603. [CrossRef] [PubMed]

35. Anandharaj, M.; Sivasankari, B.; Santhanakaruppu, R.; Manimaran, M.; Rani, R.P.; Sivakumar, S. Determining the probiotic potential of cholesterol-reducing Lactobacillus and Weissella strains isolated from gherkins (fermented cucumber) and south Indian fermented koozh. Res. Microbiol. 2015, 166, 428-439. [CrossRef]

36. Choi, A.R.; Patra, J.K.; Kim, W.J.; Kang, S.S. Antagonistic activities and probiotic potential of lactic acid bacteria derived from a plant-based fermented food. Front. Microbiol. 2018, 9, 1963. [CrossRef]

37. Abriouel, H.; Lerma, L.L.; Casado Muñoz, M.D.C.; Montoro, B.P.; Kabisch, J.; Pichner, R.; Cho, G.S.; Neve, H.; Fusco, V.; Franz, C.M.A.P.; et al. The controversial nature of the Weissella genus: Technological and functional aspects versus whole genome analysis-based pathogenic potential for their application in food and health. Front. Microbiol. 2015, 6, 1197. [CrossRef]

38. Benkerroum, N. Biogenic amines in dairy products: Origin, incidence, and control means. Compr. Rev. Food Sci. Food Saf. 2016, 15, 801-826. [CrossRef]

39. Barbieri, F.; Montanari, C.; Gardini, F.; Tabanelli, G. Biogenic amine production by lactic acid bacteria: A review. Foods 2019, 8, 17. [CrossRef]

40. Noens, E.E.; Lolkema, J.S. Convergent evolution of the arginine deiminase pathway: The $\operatorname{ArcD}$ and $A r c E$ arginine/ornithine exchangers. MicrobiologyOpen 2017, 6, e00412. [CrossRef]

41. Schillinger, U.; Holzapfel, W.H.; Björkroth, K.J. 20-Lactic acid bacteria. In Food Spoilage Microorganisms; De W Blackburn, C., Ed.; Woodhead Publishing: Cambridge, UK, 2006; pp. 541-578.

42. Papadia, C.; Osowska, S.; Cynober, L.; Forbes, A. Citrulline in health and disease. Review on human studies. Clin. Nutr. 2018, 37, 1823-1828. [CrossRef]

43. Figueroa, A.; Wong, A.; Jaime, S.J.; Gonzales, J.U. Influence of L-citrulline and watermelon supplementation on vascular function and exercise performance. Curr. Opin. Clin. Nutr. 2017, 20, 92-98. [CrossRef]

44. Aktaş, K.; Akın, N. Influence of rice bran and corn bran addition on the selected properties of tarhana, a fermented cereal based food product. LWT Food. Sci. Technol. 2020, 129, 109574. [CrossRef]

45. Kato, H.; Rhue, M.R.; Nishimura, T. Role of Free Amino Acids and Peptides in Food Taste. In Flavor Chemistry Trends and Developments; Teranishi, R., Buterry, R.G., Shahidi, F., Eds.; American Chemical Society: Washington, DC, USA, 1989; Volume 388, pp. 158-175.

46. Moongngarm, A.; Daomukda, N.; Khumpika, S. Chemical compositions, phytochemicals, and antioxidant capacity of rice bran, rice bran layer, and rice germ. Apcbee Procedia 2012, 2, 73-79. [CrossRef] 
47. Demirci, T.; Aktaş, K.; Sözeri, D.; Öztürk, H.İ.; Akın, N. Rice bran improve probiotic viability in yoghurt and provide added antioxidative benefits. J. Funct. Foods. 2017, 36, 396-403. [CrossRef]

48. Kurdi, P.; Hansawasdi, C. Assessment of the prebiotic potential of oligosaccharide mixtures from rice bran and cassava pulp. LWT Food. Sci. Technol. 2015, 63, 1288-1293. [CrossRef]

Publisher's Note: MDPI stays neutral with regard to jurisdictional claims in published maps and institutional affiliations.

(C) 2020 by the authors. Licensee MDPI, Basel, Switzerland. This article is an open access article distributed under the terms and conditions of the Creative Commons Attribution (CC BY) license (http://creativecommons.org/licenses/by/4.0/). 